\title{
CALLING UPON A DOMOVOI IN THE CHILDREN'S GAME TRADITION OF THE KOMI
}

\author{
Aleksey Rassykhaev \\ Researcher \\ Department of Folklore, Institute of Language, Literature, and History \\ Komi Science Centre of the Russian Academy of Science, Russia \\ Email: rassyhaev@mail.ru
}

\begin{abstract}
This article deals with the children's game of calling upon a domovoi ${ }^{1}$, which is unique for the traditional spiritual culture of the Komi. New authentic texts as well as archival material that has never been used before is cited. Their analysis allows the area of the spread of this game to be expanded. According to the new sources, it did not only exist among the Komi living on the shores of the basin of the Vychegda River (with the tributaries of the Vishera, the Vym, and the Sysola), but also among the northern Komi-Permiaks in the traditions of Kosinsky District. The games have similar scenarios and are aimed at establishing contact with the invisible inhabitant of the house living in the cellar, and checking if it really exists. The most noticeable variation exists in the names of the demonym, poetic addresses, and characteristics. The image and terminology pertaining to the domovoi addressed in the game contain reflections of mythological concepts that are similar to 'adult folklore', but quite often the addresses to the character called upon take on the features of 'childishness', i.e., diminutive forms, reduplication, and personal names. In the context of experiencing collective fear, this game is close to the magically playful calling upon the neo-mythopoetic characters (the Queen of Spades, a Dwarf, devils, etc.), which is common among modern schoolchildren, including the Komi schoolchildren.
\end{abstract}

Keywords: children's game, domovoi, Komi folklore, Komi-Permiak folklore

\section{INTRODUCTION}

A children's game involving calling upon a domovoi from the cellar is specific to the Komi folk culture. In scientific literature, it has two names: Yuri Rochev figuratively calls this game гӧбӧч айка 'the spirit of the cellar' (the researcher translates the name as the 'lord of the cellar') (Rochev 1972: 135; 1979: 219), while Dmitry Nesanelis refers to it as a гӧрд гача (literally 'wearing red trousers') (Nesanelis 1994: 95). 
This game was the subject of a separate research by Nesanelis, who considered it from the ethno-semiotic perspective in the article titled "Старинная игра детей коми 'гӧрд гача': Опыт семантического анализа” (The Ancient Game 'görd gacha' of the Komi Children: Semantic Analysis) (Nesanelis 1989). The author analyses the most notable features of this house spirit that children call upon from the cellar, such as flabbiness that can be compared with clay, the red colour of its body and clothing (trousers) that is often perceived in a negative way, and its colourfulness which, in the opinion of the researcher, make it possible to bring it nearer to the mythological 'Purusha'. During the game, children actualize their perceptions of the spatial opposition of up and down (the domovoi in the cellar), the opposition of the things that are your own and someone else's (friend/foe), the ancestors' world and the world of the living, chaos and space. While accepting a number of standpoints expressed in the research, I will pay special attention to the facts that have been unaddressed so far. Mainly I will be citing authentic texts recorded in recent decades, and expanding the geography of the distribution of this game.

\section{DESCRIPTION OF THE GAME}

From the perspective of typology, this game can be called funny, a kind of an impromptu game, since it does not follow any specific rules that exist in the majority of other games, such as the game leader, punishing a player that has lost, etc.

The first description of this game that we know about was given at the end of the nineteenth century by Leonid Kaplin, a student of Vologda Theological Seminary, who recorded the existence of this game in Derevyansk village in the area of the Vychegda River:

Several young men gather together in a house, and they close the windows so that it will go dark. They sit on benches with their legs raised so that the domovoi does not cut them with a scythe or a sickle. They push the doors of the cellar wide open. One young man is standing on a chair near the entrance, with a stick in his hand, striking it against a chair, saying: "Our neighbour and brother, come out, come out, and taste our water, bread, and salt". After he has said that, the domovoi rolls out of the cellar on rugs in the shape of an egg. After waiting a little, the players rush to open the windows to see whether it was a domovoi or not. If you throw a log into that egg (the domovoi), it will pour out gold and silver. ${ }^{2}$ (Nesanelis 1999) 
In his work, Kaplin mentions other names of the domovoi as well, for example, виж кок 'the yellow foot', recorded in the village of Veslyana, which stands on the Vym River (the current Knyazhpogostsky District). At the beginning of the game, children would close the windows and stick a knife into the floor in front of the entrance to the cellar (Nesanelis 1999).

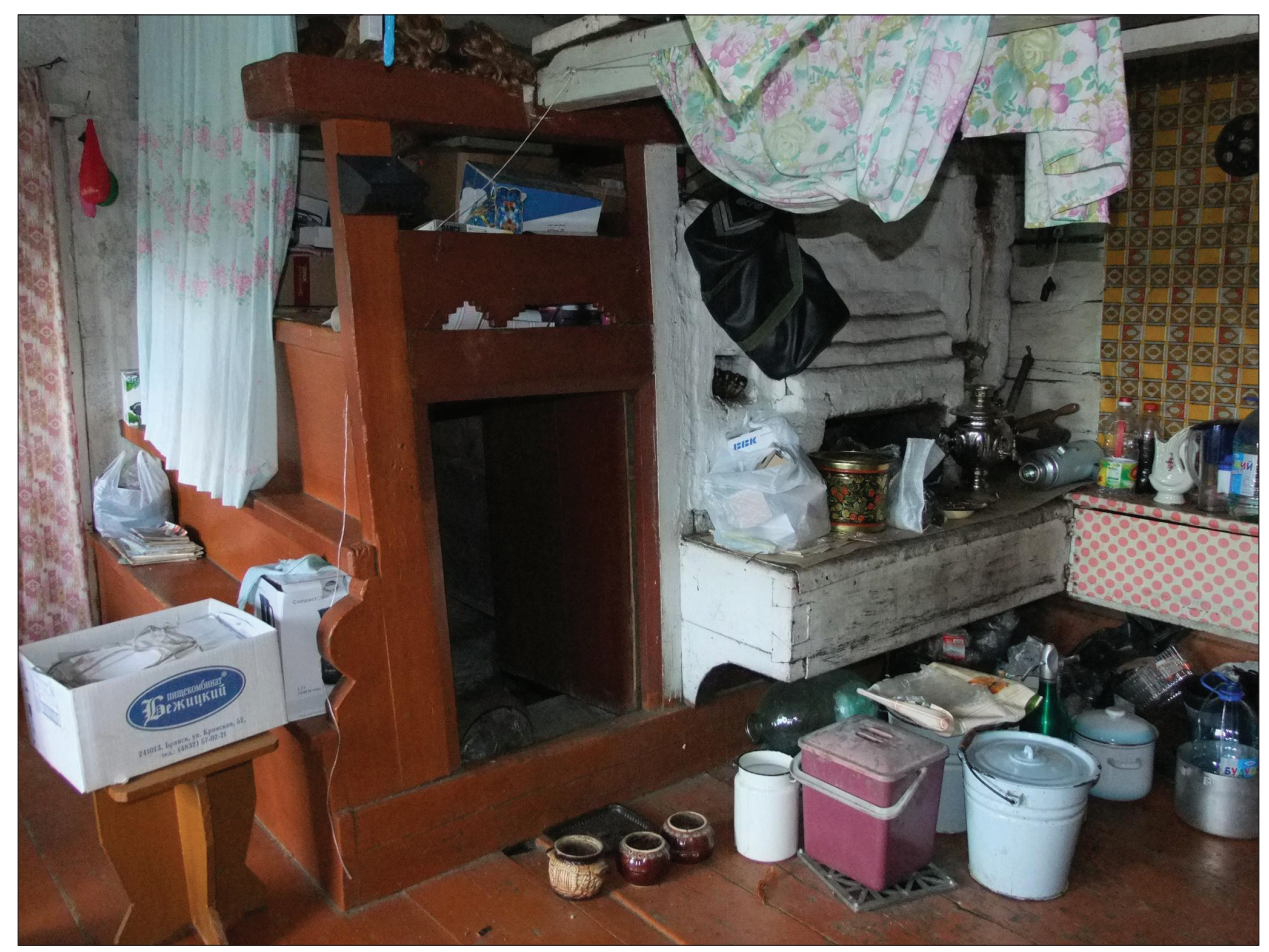

Figure 1. Entrance to the cellar, in front of which the game is usually played. Village of Bolshelug, Kortkerossky District. Photograph by Aleksey Rassykhaev 2015.

The second description of the game from top down was made by A. E. Agafonova, a student of the Komi Teachers' Training College, who recorded a game named орт петкӧдӧм 'taking out the soul-ort's, in Syktyvkar in 1935. Children would curtain the windows, put water and bread next to the cellar doors and address the domovoi together: 




Figure 2. Entrance to the cellar, in front of which the game is usually played. Painting on the stove is an example of the modern naive art. Village of Veslyana, Knyazhpogostsky District. Photograph by Liudmila Lobanova 2016.

Гӧбӧч улысь пачсай айка, Петав жӧ, петав, Вым няньӧн вердал, Пань тыр ваӧн юкталал! ${ }^{4}$
The spirit who lives behind the stove, come out of the cellar, we will give you bread and butter to eat and give you water to drink!

In the comments made about the game it was pointed out that, while calling upon the domovoi, players would sometimes collapse because of fear.

From other descriptions we learn that the game was most often played in summer (during the haymaking period) when adults were out in the field. After closing windows in the house and putting bread and salt right next to the entrance to the cellar, children would take a fire iron and climb on the stove, from which they called upon 'the neighbour and brother'5 (Sorvacheva \& Zhilina 1971: 72-73). In other versions of the game children climbed on the sleeping 
bench, trunks, and benches, and would take scissors, knives, sticks, pounders, or oven forks in their hands:

Тупкалал ӧшиньяс, укват босьтали, да уквата мортіс каяс лабиче, а мукедіс ворсэні джоджин. Ставніс шувалэні: Пи-пи тойин, петаллі, Ива Шорлэн нянис кылэ, Поплэн нянис сотче! Ӧшиньтэ костэдіштаснь и югидіс югдэдас, сэк горедал: "Пипи тойин петэ!" Эсся ставен пьциялм, полал да. ${ }^{6}$
Let us close the windows, take an oven fork, and the person with the oven fork should stand on the bench. Others are playing on the floor. Everyone says: $\mathrm{Pi}-\mathrm{pi}^{7}$ the pounder, come out, There is a smell of bread at Iva Shor's ${ }^{8}$, Bread is burning at the priest's house! We would open [a curtain], and a ray of light would come in, and then we would shout: 'Pi-pi the pounder is coming out!' And then we would all run away, because we were scared.

In some versions of the game, one of the players (the oldest and the most experienced) enters the cellar before the game starts and then walks out of it after saying specific words. There are over twenty descriptions of this game at our disposal, the scenarios of which virtually do not differ from the ones listed above.

\section{THE DISTRIBUTION OF THE GAME}

According to the publications of Rochev and Nesanelis, the geography of the game of calling upon the domovoi from the cellar is limited to three districts of the Komi Republic: Ust-Vymsky, Ust-Kulomsky, and Syktyvdinsky districts. The analysis of archival sources and expeditions has allowed the area of the distribution of the game to be expanded along the shores of the Vychegda River (with the tributaries of the Vishera, the Vym, and the Sysola), where it was recorded in the following inhabited localities: Veslyana village in Knyazhpogostsky District; Ust-Vym village in Ust-Vymsky District; the villages of Ozel and Pazhga in Syktyvdinsky District; the city of Syktyvkar; the villages of Kuratovo and Mezhador in Sysolsky District; the villages of Bolshelug, Vazhkurya, and Nivshera in Kortkerossky District; and the villages of Anyb, Derevyansk, Don, Kerchomya, Nizhny Voch, Pozheg, Pomozdino, and Ust-Kulom in UstKulomsky District. 
Additionally, while conducting field research among the Komi-Permiaks who lived in the Komi-Permiak Okrug in Perm Krai in 2011, the author of this work recorded a similar game in the villages of Churaki and Puksib in Kosinsky District. ${ }^{9}$ What follows is a description of the 'Susedushko' ('Neighbour') game (суседушкоьсь орсльллілӧ) recorded in the village of Churaki:

Няньис эл дак, картокаторрез да If there is bread in the house, you няньторрез пуктан, крӧшитан take potatoes and bread, crumble бекӧрӧ да, джоджуллэз вӧллісӧ, them onto a plate. There used to осьтан да, сія джоджулсӧ осьтан, сэтчин льиикӧ вылас, пуктан лабич вылас, и босьтан укват ли заступ ли и сійӧн керку гӧгӧрат [нрзб]:

Суседушко-вартанушко!

Хлебушко да соль,

Ми тәд пуктіли.

Миянль бурджька кер!

Сія ешшӧ сольцтан дак. Сія кьскан - дак сэтшӧл чӧскьљы be cellars [in houses], so you would open the cellar and put a plate with bread and potatoes on the bench, then you would take an oven fork or a spade and bang with it [all around the house]:

Our neighbour, our brother!

We have brought

bread and salt to you.

Do some good for us!

Сусеткуыс сія сэтчӧ солалас сэсся. Ӧддьӧн сійӧн лььрддььıсял да сёял. [...] A кор нянььє вӧлі, сэки и орсали, кор окота сёйнь. ${ }^{10}$

And then you put salt on that

[bread]. It is so delicious when you take it out! Susetku would put some salt on it. And then we would grab it away from each other and eat it. ... We would play that game when there was bread, when we were hungry.

It was the first time when the existence of this game among the Komi-Permiaks was observed. The fact of making a recording of this game among the KomiPermiaks expands the area of distribution of this children's game of calling upon the domovoi and allows us to talk about a possible existence of the contact area somewhere on the banks of the Upper Vychegda or the Upper Kama. The northern part of Kosinsky District of Perm Krai borders on the southern inhabited localities of Ust-Kulomsky District of the Komi Republic, in which the game under consideration, according to the data collected, is mostly developed. 


\section{TERMINOLOGY}

The game under consideration has a number of different names, the most important discriminating feature of which is the name of the domovoi that is called upon. The name of this mythological character mainly appears in poetic addresses to him. In the saying within the game some of the names originate from Russian demonym words, such as $\partial e \partial$ 'old man, grandfather' and суседко 'dear neighbour', by adding diminutive forms and rhymed paired words: суседушка-братанушко 'dear neighbour-brother' (Derevyansk), соседушковоседушко 'dear neighbour' (Anyb), дедушка-бедушка 'dear grandfather' (UstKulom), дедӧ-бедӧ 'old man, grandfather', дедушко-бедушко 'dear grandfather' (Bolshelug), дедушко 'dear grandfather' (Pazhga). In the same line, we should consider the semantic doubles дедӧ-пӧльӧ (пӧльӧ 'a father's father, a grandfather') (Kuratovo and Mezhador). It is worth noting that the addresses суседушко and $\partial e \partial$ are regularly used in various sayings that are uttered in Komi rituals related to cattle raising.

In the Upper Vychegda versions, the names with the second part containing the word тоин 'pounder' have been recorded. The first part is sometimes too difficult to understand; however, it can still be etymologized with a degree of likelihood: пипу тоин 'aspen pounder' (Pozheg, Nizhny Voch, Pomozdino); nи-пи тойин (Pozheg, Vazhkurya), припетойuн (Kerchomya), npune is a desemantisation of the word nuny 'aspen'. It might be the case that aspen was used for making pounders, which translated into the name of the domovoi in the game. It is notable that, according to the information provided by one of the informants, a pounder is used as a game attribute:

Сыц гӧлбӧчтӧ йигналан вӧлі.

Сэсся занавесалан ӧшиньяснылӧс.

Сэсся челядь чукарыљ босьтан

мьıйкӧ, этія гырйын тойин

выйил, да кералан:

Припетойин, пет жӧ, пет, Сера кычи, эн жӧ пет! $!^{11}$
The cellar was locked. Then

windows were curtained. Then the children took a pounder and started banging with it:

Pripetoiin, come out, come out, Spotted puppy, don't come out!

Some of the names refer to the colour and a general description of the character called upon from the cellar: шыра-каня, матушка 'a mouse and a cat, a mother' (Don), кос петук 'a dry cockerel' (Ozel), виж кок 'a yellow foot' (Veslyana), гӧрд косаа 'with a red plait', гӧрд гача 'wearing red trousers', гӧбӧч айка 'the spirit of the cellar' (Syktyvkar). 
In some cases, the domovoi was attributed with a human name that was used for scaring naughty children: чурка Микипер 'bastard Nikephoros' (Nizhny Voch), чилля Ёгор 'Egor with a penis' (Pomozdino).

In the Komi-Permiak version of the game, the domovoi is referred to as a суседушко-вартанушко 'a neighbour' (Churaki) or сюсю-баба (Puksib). It is possible that the word вартанушко is reduplicative from the word вартан, i.e., a threshing flail; something that is used for banging around while calling upon domovoi, to make some noise; or from братанушко (compare with the demonym суседушка-братанушко recorded in Derevyansk). It can be assumed that сюсю is the reduced stem of the words суседушко or сусеткy, which are used to refer to the mythological character in the Kosinsky folklore tradition. The answer that was given by the informant to the question 'Who is Syusyubaba?' is remarkable: - 'A cусеткуыс! Cусетку сія. А мыцй нӧ, орсіканылм бара Сюсю-бабаӧн шуал' ('This is susetku. Susetku. In the game, we call him Syusyu-baba'). ${ }^{12}$

Meanwhile, in the addresses within the game no such names of the character that are widespread in folklore traditions, in which the game of calling upon the domovoi existed, can be observed: бубыля (Syktyvkar), бубиля (Dereviansk, Kerchomia) ${ }^{13}$, бубуля (Syktyvkar), бубуня (Middle Sysola), буба (Bogorodsk) (SSKZD 1961: 28); олься, оліся, ольсь 'the living thing; the inhabitant' (SSKZD 1961: 259); керка видзысь 'the guardian of the house'.

After having studied the names for the domovoi used in games, it can be assumed that a ban on directly naming this mythological character is related to reducing the children's fear of something unknown and inexplicable and creating the situation that is as favourable for contacting supernatural forces as possible.

\section{MYTHOLOGICAL MOTIFS OF THE GAME}

In the game of calling upon the domovoi there are a number of archaic perceptions, which has already been mentioned before (see Nesanelis 1989). However, within the framework of this paper, I will point out some other mythological motifs related to Komi traditions. In order to generate favourable conditions for contacting the spirit of the cellar, players make some changes in the room: they curtain windows in the house, creating twilight as the most suitable environment for the encounter with supernatural forces: 
Ӧшиньяссӧ тупкалал, асьнім пӧлате каям. Коді бедь босьтас, коді пурт, кокалюкаяс, ся горзал: Кос петук, nem, nem! $!^{14}$
We would close the windows and climb onto the sleeping bench. Some of us would take a stick, or a knife, or a fire iron, and then we would shout: Dry / Skinny cockerel, come out, come out!

Children would introduce some destructive elements into the game experience which are specific for other ritual and transitional calendar and life situations: turn icons in the icon case upside down, just like while fortune-telling (Semyonov 1991: 65); turn fur coats inside out or put on some disguises similar to those worn before Christmas (Nesanelis 1994: 56):

Вӧльи ӧшиньяс тупкаласны, ен гугӧдасны да гугапасясяснь, да кодкӧ пьрас гӧбӧчӧ, да вӧльь шуалал:

Дедушко-бедушко, петов тэ, nетов! ${ }^{15}$
We would curtain the windows, turn the icons upside down, and turn our fur coats inside out, and then someone would enter the cellar, and we would say:

Dedushko-bedushko, come out, come out!

In order to make contact with the domovoi, the sound code is also incorporated, i.e., the players bang with pounders, fire irons, oven forks, sticks, or spindles against the floor or the door of the cellar, snap with scissors, and run around with a fire iron squeezed between their legs:

Сувталасньь, ӧтик босьтас коколюка кок вож костас котравны джодж кузяьс:

Чилла Ёгор, петалль,

Чилля Ёгор, петалль!!

И сійӧ ноксигкост тіьсс чӧвтаснь гӧбӧчас коколюкасӧ и ставыс котӧртаснь - каясны паччӧрас. ${ }^{16}$
They would stand in the middle of the room, with a fire iron squeezed between their legs, and run around in circles:

Chillya Yogor, come out!

Chillya Yogor, come out!

And then, right in the middle of running around, they would throw the fire iron into the cellar and scatter, climbing the sleeping bench on top of the stove.

The invitation to taste the food (either fresh or salty water, salt, bread with butter, potatoes) offered to the domovoi can be compared with the act of feed- 
ing 'the old folks' (dead ancestors) in the house in the morning time or at the cemetery after a funeral. In addition to asking the domovoi to come out from the cellar and taste food (in one of the texts, the domovoi was asked to mow the grass in the pasture), some games also incorporate threats and lay down conditions for the spirit of the cellar in case it fails to obey the orders of the players:

Суседушка-братанушка, Чеччыв жӧ, чеччыв!!

Суседушка-братанушка,

Петав жӧ, петав!

Он кӧ петав,

Кӧрт коколен клёнӧдал, клёнӧдал. Петалан кӧ,

Мича паньӧн паньӧдал, паньӧдал, Выцй паньӧн паньӧдал, паньӧдали. ${ }^{17}$
Susedushka-bratanushka, rise up, rise up!

Susedushka-bratanushka, come out, come out!

If you don't come out,

we'll beat you with an iron stick, we will. And if you come out, we will feed you from a beautiful spoon, we will feed you with a spoon of butter.

Calling upon the domovoi from the cellar is accompanied by experiencing collective fear while verifying the existence of the locus of the lower world and its inhabitant:

Эсся ставньли ланьтлали. Видзӧдали - эз на пет, оз пет. Куилььсь кылмын сььлал. Сәсся кодкӧ и ӧти горӧдас - петіс пӧ. Сэсся сія и повзыььссяс дзӧляасьљ. Господи! О-о-й, сэсся сія ставыс кутан дзебсььны. “Oü-oŭ, nemic, oŭ-oŭ, nemic”. Ömu юалӧ: “Кутшел?” Дзӧляясыд: “Кутшел?”- “Югыд синлиа!”“Сюра абу?” Да ӧд колӧ жӧ вӧлі челядьсӧ повзьӧдлььны тайӧн! 18
Then we would all become silent. And we would look to check whether it has come out or not. We would sing a song calling it out three times, and then someone would shout out: It has come out! The smallest ones would be extremely scared. Oh my God! And then everyone would start hiding. 'Oh, oh, it's come out, it's come out!' One of us would ask: 'What is it like?' The smallest ones would ask: 'What is it like?' - 'Its eyes are glistening!' 'Does it have horns?' Yes, we were scaring the kids with that!

In the opinion of Nesanelis, 'in the localization of the domovoi (the cellar) and the playing children (the sleeping-bench), the perceptions of the spatial opposition of the up and down were represented very clearly. While for adults the perceptions of the vertical structure of a dwelling mainly unfolded through rituals related to construction, for children they were actualized in the course 
of the game' (Nesanelis 1994: 104-105). Thus, while playing, children adopt the basics of the vertical and horizontal segmentation of space.

On the one hand, in the game, children are flirting with the domovoi, calling it out from the cellar, while on the other hand, they fear meeting it. Similar behaviour is typical of game situations when players tease, befool, and delude the game leader who is invested with the features of mythological characters (one-legged, blind-folded, capacity for immobilization, moving like the wind), and at the same time they are doing their best not to be caught by him (Rassykhaev 2014: 108-109).

The name of the demonym and its main features and attributes are contained in the saying within the game - wearing red trousers, having a plait, having glistening eyes, being spotted. For example, in Kerchomya versions of the saying (Upper Vychegda tradition), the players forbid the spotted puppy (сера кыıи) to come out of the cellar. I believe that in this case, this particular domestic animal is one of the incarnations of the mythological character. In Russian folklore, the domovoi also shows itself to people in the shape of a dog. As an example, I am citing the following text from the Russian tradition proximate to the Komi: '(What is it like?) She [granny-nanny] used to say that it was shining and looked like a big dog. And where? What was it like? We never saw it.'. ${ }^{19}$

There is no doubt that the game image of the domovoi incorporates both the mythological practices of adults and children's perceptions of the invisible spirit. It can be assumed that the perceptions of the children concerning this character from the lowest mythology are also based on traditional intimidation of children using the domovoi. Such intimidation aims at nurturing children and keeping them from injuries that children can get as a result of falling into the cellar. The cellar was not only a place where food was stored (bread, baked goods, potatoes, etc.), but also a place with an increased risk to children.

In some traditions, calling upon the spirit of the cellar transformed into intimidating children. An informant from the village of Bolshelug remembered her childhood when, once on a winter day, she was invited to a house next door to call upon дедё-бедё, and asked to climb the sleeping bench on top of the stove. After calling for the domovoi, a monster wearing rags, a hat, and a beard stepped out of the cellar, which scared away the kids. Later on the children recognized the girl next door in that monster. They believed that if the domovoi caught a child, it would fall asleep for good. ${ }^{20}$

The game of calling upon the domovoi was forced out of the game repertoire in post-war years, but it was ultimately forgotten among Komi children in the 1970s. The next stage of this children's game was playing by the rules. Today only stories about how this game used to be played before circulate. For example, this is how a student of Syktyvkar State University describes this game according to her grandmother (ьљжыд мам): 
Ная челядь чукӧр чукӧртчаснь керкаас, кодлӧн ьцжыдъясыс абуӧсь. Сэсся занавесъяссӧ ставсӧ вешталасны, мед пельљ вӧлі керкаас. Эсся кутшӧмкӧ мортӧс, но тоже пудиясясны, ӧти мортӧс пасьтӧдасны гӧна пасьӧн, и пырас сійӧ гӧбӧчӧ. Эсся гӧбӧчсӧ сиптасныь. Сэсся сэн мыцйкӧ шаманитасны, ог тӧд, мыйкӧ шуаласны, шуаласны. И сійӧ кор петӧ, сійӧ, сэн жӧ ичӧт челядь тшӧтш ворсӧны, ичӧт челядьыс пӧ зэв ёна вӧлі бӧрдӧньь и котралӧны керка пасьталаас. И этія, кодӧс пӧ суас, сійӧс пӧ вӧлі гӧбӧчас и пыртас. Чукӧртӧ ӧтикан. Сэсся коді кольӧ, сэсся сійӧ гӧна пасьнас пасьтасьӧ.. ${ }^{21}$
They, children, would gather together in the house of a child whose parents were not [at home]. They would close all the curtains so that it would be completely dark in the house. Then they would have a tossup and choose a person and put a fur coat on him, and he would enter the cellar. Then they would close the cellar door. They would tinker a little, I don't know if they were saying something. And when he stepped out of the cellar, he would play with the smallest kids, but they would cry out loud and run around the house. And they used to say that he would take the ones he caught down to the cellar with him. He would take them one by one. And then the one who was left would put on a fur coat.

In the context of experiencing collective fear, the game under consideration is close to the magically playful calling upon neo-mythopoetic characters (the Queen of Spades, a Dwarf, devils, etc.), which is common among modern schoolchildren, including the Komi schoolchildren. For the participants in the 'ritual', which also takes place in the darkness and with no adults around, it is important to make contact with supernatural creatures, using a mirror, and to find traces of their presence in the room (Novitskaya \& Raykova 2002: 44). They are different from calling upon the domovoi in the Komi tradition in that during the modern ritual, a wish is made, which resembles a kind of a hypnotic session that ends with breaking a mirror into pieces or burying it.

\section{THE SAYING IN THE GAME}

Every description of the game includes a verbal accompaniment, which consists of a poetic address to the domovoi and a call for it: to come out from the cellar, to taste food - bread with butter and salt, water. 
In spite of the fact that in some descriptions informants use the lexis that refers to the group singing of these lines (челядь артельӧн сьылӧньь 'children sing in chorus'; а сьылали тайӧ 'and this is what we sing'; пондал сьыны челядь чукар 'we, a whole passel of kids, start singing'); in the comments, informants most often talk about saying those lines: ставніс шувалэні 'everyone says', дедушкоӧс корим 'we called the old man', челядьдырйи шулім 'in the childhood, they said', войдӧр вӧлі чуксалласнь 'we used to call it upon', ся горзал 'then we would shout out loud'. What is more, one and the same informant can use the lexis referring both to singing and saying:

Сәсся тай кутан шуны:

Суседушка-вӧседушка, Чилье-чилье, петав, петав!

[...] Тая вӧлі сььланкьвиясьљ, век вӧлі сььллӧны. ${ }^{22}$
Then we would say:

Susedushka-vosedushka, Chilye-chilye, come out, come out! ... Those were the songs, we would always sing them.

The uncertainty related to the way of uttering the texts (singing or saying them) proves the opinion expressed by Aleksandr Belousov, who said that in folklife culture, there is text diffusion and no clear separation between game refrains and game sayings: 'one and the same text can exist both in the form of a refrain and of a "rhyme" / "a saying" (Belousov 1989: 12).

\section{CONCLUSIONS}

The analysis of the descriptions of the game of calling upon the domovoi in the Komi tradition, presented in this paper, allows the borders of existence of this children's game to be expanded. It was widespread not only among the Komi peoples living on the shores of the basin of the Vychegda River (with the tributaries of the Vishera, the Vym, and the Sysola), but also among the northern Komi-Permiaks in the traditions of Kosinsky District. This game is unique and has no parallels in the traditions of other peoples. The image and terminology pertaining to the domovoi addressed in the game contain some perceptions that are similar to 'adult folklore', but quite often the addresses to the character called upon take on the features of 'childishness' (diminutive forms, reduplication, personal names). While playing, children actualize numerous ontological perceptions of the nature of fear, the essence of a mythological character, the binary 'friend/foe' opposition, and the vertical spatial structure. 


\section{ABBREVIATIONS}

SA Komi SC - Scientific Archive of the Komi Scientific Centre of the Ural branch of Russian Academy of Sciences

NMKR - National Museum of the Komi Republic

FDA - field data collected by the author

FA of SSU - Folklore Archive of Syktyvkar State University

\section{NOTES}

1 A protective house spirit.

${ }^{2}$ It is curious that instead of children, young men take part in the 'game', while mythological perceptions of the domovoi bringing gold and silver have strong parallels in superstitious Russian prose. For example, in the village of Nyuchpas in Koygorodsky District in the Komi Republic a popular belief was recorded, which had been told by the ancestors of the Russians who had moved here from the Vologda, Vyatka, and Kostroma governorates, which said that if you touch a domovoi, it will pour out silver or gold (Lobanova \& Nizovtseva \& Rassykhaev 2014: 27, 41): 'We had this old lady Shevelikha. She would give us a fright; we would be so afraid to come out of the house. "He is coming, she said, he is going to get you ... (How did she say that...?) the domovoi is coming, and if you touch him, he will pour out gold". And we would walk around looking for him. But no one could ever find him anywhere' (recorded by A. Rassykhaev in the village of Nyuchpas, Koigorodsky District, Komi Republic, on 4 June 2011 from G. N. Mikhailova, born in 1928 (FDA)).

${ }^{3}$ An ort is a mythological spiritual counterpart of a human being (Rochev 1985).

4 Recorded by A. Agafonova in Syktyvkar in 1935 (NMKR: KP-12484. L. 157 ob.).

5 Recorded by E. Guliaev in the village of Derevyansk, Ust-Kulomsky District, in 1963.

${ }^{6}$ Recorded by M. Sakharova in the village of Pozheg, Ust-Kulomsky District, on 26 March 1963, from P.P. Luzhikova (SA Komi SC: F. 1. Op. 11. D. 227. L. 204).

$7 \mathrm{Pi}$-pi-perhaps the desemantisation of the word nuny 'aspen' took place.

8 Iva Shor in this context might be a nickname of a fellow villager.

9 I gratefully acknowledge Elena Fedoseeva, a research fellow from the Institute of Language, Literature and History of the Komi Scientific Centre, for providing me with advice concerning Komi-Permiak dialectology.

${ }^{10}$ Recorded by A. Rassykhaev in the village of Churaki, Kosinsky District, Komi-Permiak Okrug, Perm Krai, on 16 July 2011, from V.V. Fedoseeva, born in 1928 in Churaki (FDA).

${ }^{11}$ Recorded by Y. Rochev in the village of Kerchomya, Ust-Kulomsky District, in June 1977, from E.F. Tarabukina, born in 1930 (SA Komi SC: F. 5. Op. 2. D. 218 a. L. 191. No. 80. L. 191). 
12 Recorded by A. Rassykhaev in the village of Puksib, Kosinsky District, Komi-Permiak Okrug, Perm Krai, on 17 July 2011, from N.S. Fedoseeva, born in 1932 in Puksib (FDA).

${ }^{13}$ An exception of a description of the game recorded in the village of Kerchomya in Ust-Kulomsky District: the domovoi is called upon by saying 'Сера бубыль, nem, nem, nem!' (Spotted bubylya, come out, come out!) (Paniukov \& Savelyeva 1999: No. 98).

${ }^{14}$ Recorded by N. Loskutova and G. Baraksanov in the village of Ozel, Syktyvdinsky District, on 8 December 1965, from K.I. Lytkina, born in 1898 (SA Komi SC: F. 1. Op. 11. D. 264. L. 131).

${ }^{15}$ Recorded in the village of Male, Pozhegodsky Rural Municipality, Ust-Kulomsky District, in 1995, from N. S. Martiushev, born in 1938 (FA of SSU: 1213-3).

${ }^{16}$ Recorded in the village of Pomozdino, Ust-Kulomsky District, from P.V. Ignatova, born in 1921 (FA of SSU 1214-19).

${ }^{17}$ Recorded by Y. Rochev in the village of Derevyansk, Ust-Kulomsky District, in June 1977, from I.A. Guliaeva, born in 1910 (SA Komi SC: F. 5. Op. 2. D. 218 a. L. 212. No. 88).

${ }^{18}$ Recorded by Y. Rochev in the village of Derevyansk, Ust-Kulomsky District, in June 1977, from I.A. Guliaeva, born in 1910 (SA Komi SC: F. 5. Op. 2. D. 218 a. L. 212-213. No. 88).

${ }^{19}$ Recorded by A. Rassykhaev in the village of Nyuchpas, Koygorodsky District, Komi Republic, on 4 June 2011, from G.N. Mikhailova, born in 1928 (FDA).

${ }^{20}$ Recorded by A. Rassykhaev in the village of Bolshelug, Kortkerossky District, on 16 June 2015, from L.M. Gabova, born in 1927 (FDA).

${ }^{21}$ Recorded by A. Rassykhaev in Syktyvkar on 20 December 2013, from V.S. Lodygina, born in 1995 in Kerchomya, Ust-Kulomsky District (FDA).

${ }^{22}$ Recorded by Y. Rochev in the village of Anyb, Ust-Kulomsky District, in June 1977, from A.D. Paniukova, born in 1894 (SA Komi SC: F. 5. Op. 2. D. 218 a. L. 308. No. 145).

\section{REFERENCES}

Belousov, Aleksandr 1989. Detskii fol'klor: lektsiia dlia studentov-zaochnikov. [Children's Folklore: A Lecture for Extramural Students.] Tallinn: Tallinnskii pedagogicheskii institute.

Lobanova, Liudmila \& Nizovtseva, Svetlana \& Rassykhaev, Aleksey 2014. Otchet o polevykh issledovaniiakh fol'klornykh ekspeditsii v pos. Niuchpas Koigorodskogo raiona i pos. Niuvchim Syktyvdinskogo raiona Respubliki Komi v 2011 godu. [Report about Field Researches of Folklore Expeditions to the Settlement of Nyuchpas of Koygorodsky District and the Settlement of Nyuvchim of the Syktyvdinsky District of the Komi Republic in 2011.] Nauchnyi arkhiv Komi NTs: F. 5. Op. 2. D. 804. 
Nesanelis, Dmitry 1989. Starinnaia igra detei komi "görd gacha": opyt semanticheskogo analiza. [The Ancient Game "görd gacha" of the Komi Children: Semantic Analysis.] Genezis i evoliutsiia traditsionnoi kul'tury komi. Trudy IIaLI Komi NTs UrO RAN, Vyp. 43, pp. 80-89.

Nesanelis, Dmitry 1994. Raskachaem my khodkuiu kachel': Traditsionnye formy dosuga sel'skogo naseleniia Komi kraia (Vtoraia pol. XIX-pervaia tret'XX vv.). [We Are Swaying a Quick Swing: Traditional Leisure Forms of Country People of the Komi Region (The Second Half of the 19th - the First Third of the 20th Centuries).] Syktyvkar: Resp. tsentr nar. tvorchestva.

Nesanelis, Dmitry 1999. Detskie igry. [Children's Games.] In: Traditsionnaia kul'tura narodov Evropeiskogo Severo-Vostoka Rossii. Etnograficheskaia elektronnaia entsiklopediia. Available at https://ethnokomi.ru/folk/komi/138.htm, last accessed on 10 May 2019.

Novitskaya, Marina \& Raykova, Irina 2002. Detskii fol'klor i mir detstva. [Children's Folklore and the World of Childhood.] In: M. Novitskaya \& I. Raykova (comps.) Detskii fol'klor: Biblioteka russkogo fol'klora. T. 13. Moscow: Russkaia kniga, pp. 5-53.

Paniukov, Anatoly \& Savelyeva, Galina (comps.) 1999. Traditsionnaia kul'tura komi: Etnografiia detstva. Materialy fol'klorno-etnograficheskikh ekspeditsii 1995-1998 gg. [Komi Traditional Culture: Childhood Ethnography. Materials of Folkloric and Ethnographic Expeditions 1995-1998.] Syktyvkar: Gosudarstvennyi tsentr narodnogo tvorchestva Ministerstva kul'tury Respubliki Komi.

Rassykhaev, Aleksey 2014. Detskii igrovoi fol'klor komi: zhanrovyi aspekt. [Komi Children's Game Folklore: Genre Aspect.] Syktyvkar: Komi NTs UrO RAN. Available at https://illhkomisc.ru/wp-content/uploads/2014/11/rassyxaev.pdf, last accessed on 10 May 2019.

Rochev, Yuri 1972. Detskii fol'klor komi. [Komi Children's Folklore.] Diss. na soiskanie uchenoi stepeni k. filol. n. Ogarev Mordovia State University. NA Komi NTs. F. 5. Op. 2. D. 129.

Rochev, Yuri 1979. Detskii fol'klor komi. [Komi Children's Folklore.] In: Istoriia komi literatury. [History of Komi Literature.] T. 1. Syktyvkar: Komi knizhnoe izdatel'stvo, pp. 195-224.

Rochev, Yuri 1985. Traditsionnye predstavleniia komi ob orte i ikh transformatsiia v sovremennosti. [Traditional Images about the Komi ort and Their Transformation in the Modernity.] In: L. Zherebtsov (ed.) Traditsiia i sovremennost'v kul'ture sel'skogo naseleniia Komi ASSR. Trudy Instituta iazyka, literatury i istorii Komi filiala Akademii nauk SSSR, Vol. 37. Syktyvkar: Komi filial, Akademiia nauk SSSR, pp. 57-70.

Semyonov, Viktor 1991. Traditsionnaia dukhovnaia kul'tura komi-zyrian: ritual $i$ simvol. Uchebnoe posobie po spetskursu. [Traditional Spiritual Culture of the KomiZyrians: Ritual and Symbol.] Syktyvkar: Syktyvkarskii gos. un-t.

Sorvacheva, Valentina \& Zhilina, Tatyana 1971. Obraztsy komi-zyrianskoi rechi. [Samples of Komi-Zyrian Speech.] Syktyvkar: Komi filial AN SSSR.

SSKZD 1961 = Sravnitel'nyi slovar' komi-zyrianskikh dialektov. [Comparative Dictionary of the Komi-Zyrian Dialects.] Compiled by T. Zhilina \& M. Sakharova \& V. Sorvacheva. Syktyvkar: Komi knizhnoe izdatel'stvo. 